no reference to where they use the materials.

In the most general sense section 108 allows a library to photocopy any of its own materials in the interests of "preservation" of the original, without any commercial advantage and for scholarly purposes, to the extent that other purchasable copies are unavailable at the time of need at a reasonable price. With respect to unpublished manuscripts, the principal prohibition applies to copying a manuscript that the copying library does not own. Published works may be copied to replace a copy that is "damaged, deteriorating, lost, or stolen, if the library or archives has, after a reasonable effort, determined that an unused replacement cannot be obtained at a fair price." Subsequent parts (d) and (e) are concemed with interlibrary loan restrictions, which Martell handles satisfactorily.

The terms of 108 (c) cited above, especially the word "deteriorating," seem to open the door for much reserve room copying. When a scholarly journal article is assigned for class reading, no one questions the right to place the original in a reserve room. But this would create undue wear on a probably bound volume and would restrict free access to other articles from the same issue or volume. The photocopying of the article in this case is demonstrably fair use and the same is true of a chapter from a book. In either case, the library must make some effort to determine whether inexpensive reprints are available

The same principles might be extended to multiple copies for large classes if the library has taken steps to purchase multiple reprints of the item. And in the face of an inability to secure reprints, the use of the same photocopies in suc-

\section{Cataloging of Microforms}

The Subcommittee on Bibliographic Control of Microforms, RTSD/Reproduction of Library Materials Section, will hold an open meeting at the ALA Annual Conference in Chicago. Starting at 2 p.m., Sunday, June 25, the discussion will address the question of access points peculiar to microforms that should be included in an automated cataloging system. The basis of discussion will be the Library of Congress statement on Access Points for Microforms, which was distributed at the Midwinter Meeting. The Library of Congress Information Bulletin will carry the ahove statement in a spring issue to enable concerned librarians to be informed before the ALA meeting. All interested persons are urged to add their input on this important subject; comments should be forwarded to Greg Cole (chairman of the subcommittee), Ellis Library, University of Missouri-Columbia, Columbia, MO 65201

cessive school terms is at least defensible, though the library may here be required to get permission from the copyright holder at a reasonable cost.

Finally, the sharp restrictions in $108(\mathrm{~g})$ to the "isolated and unrelated reproduction or distribution of a single copy" have reference only to interlibrary loans and have little bearing on library copying for preservation of deteriorating material.-Gerald J. Eberle, Director, Earl K. Long Library, University of New Orleans.

\title{
Oregon ACRL Chapter Meets
}

The Oregon ACRL chapter met at the Lewis \& Clark College library in Portland on February 17. Marcia Lowell, state librarian, chaired the meeting. She discussed the Oregon Govemor's Conference scheduled for June $1-3$ and gave background on planning for the conference.

The ACRL members present broke into groups to discuss ideas that should be raised at the conference regarding library services, needs, and development. The results were presented to Marcia Lowell and Laurelyn Schellin, conference coordinator, to aid in setting an agenda and as expression of the concerns of academic librarians.

On March 13 the chapter met at Oregon State University to hear Pauline Atherton discuss the subject access project. On-line catalogs may not be as useful or accessible as they should be if only LC subject headings are used for description. Her experimental project expanded tra- ditional subject access points to include significant words from the index and contents page. The file that was created was then searched via the traditional entries and using the augmented information. The results of their comparison are due to be published soon.-Mary Devlin, Chairperson, Oregon ACRL Chapter.

\section{Resources in Education Worksheet Available}

A "Worksheet on How to Use Resources in Education" has been prepared by the ACRL/EBSS Committee on Bibliographic Instruction for Educators. It has been approved by the full committee and by all of the members of the EBSS Executive Board. Single copies are available from the ACRL Office. 


\section{Why build agreat collection with anything less than microform?}

Even one small room can house a great serials collection on microform. And because this space advantage is so obvious, some people tend to overlonk the other advantages of developing their holdings on microform. Consider these reasons microform will help you make your collection great:

\section{Availability.}

In depth and range, University Microfilms International's serials titles on microform are impressive. Over 11,000 serials covering hundreds of special subject areas and numerous difficult-to-obtain titles are available to you right now. And our collection is constantly being expanded to meet your needs.

\section{Durability.}

Collections developed on microform are virtually permanent and, unlike paper, are much less likely to be stolen or mutilated.

\section{Cost Savings.}

Microform is the best way to hold down the expense of building and maintaining a serials collection. Selected volumes or years, prohibitively expensive to acquire in paper, are easily affordable on microform. Even the addition of entire backfile runs amounts to a fraction of the cost of paper reprints or used editions.

\section{Enrichment Value.}

Serials on microform can fill gaps in library backfiles to provide years of uninterrupted periodical information. Or, microform can be used to round out a library's holdings. In fact, microform may be the only way serial titles of limited availability are accessible and affordable to your library.

\section{Convenient Service.}

Contact your field sales representative or call toll-free 800-521-3042 to get specific information on any title or to place an order. Al] the thought, planning, space and money that goes in to building a great collection goes farther and lasts longer on microform. Don't settle for anything less!

\section{University Microfilms Intemational}

